\title{
USE OF KB INJECTIONS FOR 3 MONTHS AT THE PUSKESMAS BALOI PERMAI, BATAM CITY
}

\author{
Muhammad Rifki ${ }^{1}$, Rosyadi Aziz Rahmat ${ }^{2}$ \\ muhammadrifki@univbatam.ac.id ${ }^{1}$, rosyadiaziz@ univbatam.ac.id ${ }^{2}$ \\ Medical Education Study Program, Faculty of Medicine, Batam University ${ }^{1}$ \\ Doctor's Professional Study Program, Faculty of Medicine, Batam University ${ }^{2}$ \\ Jl. Uniba No. 5, Batam Center
}

\begin{abstract}
Background : Injectable birth control methods use medroxyprogesterone (a type of progestin) which is injected once or 3 months into the buttocks or upper arm muscles. This is very effective but can interfere with the menstrual cycle. The results of several studies conducted on injection family planning acceptors showed that the factors associated with injection contraceptive use were menstrual disorders $51.25 \%$, $36.25 \%$ increase in body weight and an increase in blood pressure. Some of the results of studies conducted on injection contraceptive acceptors showed that factors which is associated with the use of injection contraceptives is the occurrence of menstrual disorders $51.25 \%$, weight gain $36.25 \%$ and an increase in blood pressure 3.75\% (Eiska, 2007).
\end{abstract}

Method :

The research objective was to determine the use of 3-month injection of family planning at the UPT Puskesmas Baloi Permai. The population of this study were mothers who used 3-month injection contraception. Sampling with purposive sampling technique. The number of samples is 98 respondents.

Result :The univariate results obtained were more than half of the respondents who used 3-month injection contraception $(57.1 \%)$.

Conclusion : Based on the results of the research that has been carried out, it can be concluded as follows : The conclusion in this study was that 98 respondents obtained the results, namely, respondents who used injection contraceptives for 3 months with categories using as many as 92 people (93.9\%)

\section{Keywords : Injectable KB}

\section{INTRODUCTION}

Injectable birth control methods use medroxyprogesterone (a type of progestin) which is injected once or 3 months into the buttocks or upper arm muscles. These injections are very effective but can disrupt the menstrual cycle. One third of injection contraceptive users did not menstruate at 3 months after the first injection and another third experienced irregular bleeding and spotting (bleeding spots) for more than 11 days each month. The longer the contraceptive injection is used, the more women who do not experience menstruation but less women experience irregular bleeding.

The advantages of using 3-month injection contraceptives include being suitable for preventing pregnancy or spacing out pregnancies in the long term and recovering fertility, not being affected by the "forgetting factor" of the user (unlike using PIL $\mathrm{KB})$, not disturbing the relationship between husband and wife and others. Meanwhile, the deficiency of the injection contraceptive method causes side effects on the menstrual cycle (menstruation) such as bleeding, weight gain and several other effects. Often the 3 month injection family planning acceptors do not know about the side effects of using this contraceptive method, which causes anxiety. with excessive levels of anxiety (Manuaba, 2010).

Indonesia is a country with the largest population of no. 4 in the world, namely 259 people 
(world population data sheet, 2016). Indonesia has a fairly rapid population growth rate. This can be seen from the increase in population from 119,208,229 people to $237,641,326$ in 2010. Family planning (KB) allows couples of childbearing age to anticipate births, reach the number of children they want, and adjust the distance and time of birth. they. This can be achieved through the use of contraceptive methods and infiltration measures (WHO, 2016).

\section{RESEARCH PURPOSES}

The knowledge is to find out "Use of $\mathrm{Kb}$ Injections for 3 Months"

\section{RESEARCH METHODS}

This research was conducted at the UPT Puskesmas Baloi Permai Batam City. This research method is descriptive.

\section{RESEARCH RESULT}

Table 1 Distribution of Frequency of Use of 3month injection of family planning regarding menstrual disorders in UPT Baloi Terbang City of Batam

\begin{tabular}{ccll}
\hline NO & Application & $\mathbf{n}$ & $\mathbf{\%}$ \\
\hline 1 & Apply & 92 & 93,9 \\
2 & Do not apply & 6 & 6,1 \\
\hline & Total & $\mathbf{9 8}$ & $\mathbf{1 0 0}$ \\
\hline
\end{tabular}

From table 1, it is known that it is known that the use of injectable contraceptive 3 using as many as 92 people (93.9\%) and not using as many as 6 people $(6.1 \%)$.

\section{DISCUSSION}

It can be explained from the 98 respondents that the results were that respondents who used 3 months of injection contraceptive using categories were 92 people $(93.9 \%)$.

At the time of choosing a contraceptive, women must be given information that by using the 3month injection, they will experience irregular bleeding or menstrual disorders occurring in the first year of use and long-term amenorrhoea so that women can accept this more (Suzanne, 2007). This is because injectable contraceptives containing progestins have side effects, namely irregular bleeding patterns, long bleeding episodes, spotting, and amenorrhoea, with a duration of use of 12 months or more (Kusmiran, 2011).

Side effects of family planning with menstrual cycle disorders have symptoms such as spotting and bleeding that is longer or more than usual. the cause is a hormonal imbalance so that the endrometrium experiences stiological changes. (Irianto, 2012).

According to Diana (2011), there is a relationship between the duration of injection contraceptive use and the menstrual cycle because the hormones used in injection contraception have a longer half-life in the body. But every use of contraceptives besides having benefits, disadvantages and advantages also has side effects of each contraceptive, the occurrence of side effects can be different for each individual depending on the immune system and hormonal systems in each individual's body.

Research conducted by Titing, et al (2012), The results also showed that of 198 hormonal contraceptive users, $89.9 \%$ of them were injection contraceptive acceptors and the rest were pill contraceptives. Injectable contraceptives are much more attractive to women than pill contraceptives. Meanwhile, the results of the study also showed that there was a very significant relationship between family income and the use of the contraceptive method based on the way it works, which is differentiated between hormonal and mechanical. Hormonal contraceptives include pills, injections and implants, while mechanical contraceptives include condoms, diaphragms, vaginal tissues, IUDs, and tubectomy / vasectomy.

According to research conducted by Rifai (2011), it shows that professional husbands tend to use effective contraceptives (IUD, implants, steady contraception) and those who do service jobs or menial jobs prefer noneffective contraception (condoms, pills and injections). This is reinforced by the results of the study that PUS whose income is less than the UMR tends to prefer injection contraceptives over effective contraceptive methods such as IUDs, implants, or tubectomy / vasectomy. 
When the researchers collected data in the field, the researchers conducted interviews with research subjects, 20 respondents said that the choice to use 3-month injection contraceptives was due to low economic factors, less income each month which resulted in respondents having to choose to use contraceptives for family planning. injection 3 months.

\section{CONCLUSION}

Based on the results of the research that has been carried out, it can be concluded as follows : The conclusion in this study was that 98 respondents obtained the results, namely, respondents who used injection contraceptives for 3 months with categories using as many as 92 people (93.9\%)

\section{SUGGESTION}

It is hoped that this can illustrate the condition of progestin injection contraceptive acceptors who experience menstrual cycle disorders, so that they can provide comprehensive care.

\section{BIBLIOGRAPHY}

Varney, Helen, 2001 . Buku Saku Bidan. Jakarta : EGC

Llewellyn-Jones, Derek. 2002. Dasar - dasar obsetri dan ginekologi Edisi 6,Jakarta: Hipokrates

Achmad, Maulana, dkk, 2003. Kamus Ilmiah Populer. Jakarta: Absolut

Anjani, A. D. (2017). PENGARUH PEMBERIAN

INFORMASI TERHADAP PENGETAHUAN IBU MULTIPARITAS TENTANG IMPLAN. Jurnal Kebidanan Malahayati, 3(1)

Anjani, A. D., \& NurulAulia, D. L. (2017). HUBUNGAN PENGETAHUAN KEPALA KELUARGA TENTANGBADAN PENYELENGGARA JAMINAN SOSIAL (BPJS) DENGAN KEIKUTSERTAAN DALAM PENGGUNAANBADAN PENYELENGGARA JAMINAN SOSIAL DI KELURAHAN BELIAN KOTA BATAM. Jurnal Kebidanan
Aulia, Devy Lestari Nurul; Neno, Yulisa. (2019). Pengetahuan, Sikap Dan Motivasi Pekerja Seks Komersial Terhadap Keikutsertaan Pemeriksaan Iva. Jurnal Kebidanan Malahayati 5(4). 349-356

Hartanto, 2004. Keluarga Berencana dan Kontrasepsi. Jakarta : Pustaka Sinar Harapan

Prawirohardjo, 2005 . Ilmu Kandungan . Jakarta : Yayasan Bina Pustaka Sarwono Prawirohardo

Eiska, 2007 . Keluarga Berencanan dan Kontrasepsi. Jakarta : Pustaka Harapan

Hidayat, 2007 . Metode Penelitian Kebidanan dan Teknik Analilis Data .Jakarta : Selemba Medika

Anonim, 2009 . Departemen Kesehatan Republik Indonesia . Jakarta

Pinem, 2009 . Kesehatan Reproduksi dan Kontrasepsi. Jakarta : Trans Info Media Proverawati

Maternity, Dainty; Ratna, DP; Devy, LNA. (2017). Asuhan Kebidanan Komunitas-Disesuaikan dengan Rencana Pembelajaran Kebidanan. Penerbit Andi, Yogyakarta

Dainty Maternity, S. S. T., Keb, M., \& Anjani, A. D. (2018). ASUHAN KEBIDANAN NEONATUS, BAYI, BALITA, DAN ANAK PRASEKOLAH. Penerbit Andi.

Mardhiah, A., \& Anjani, A. D. (2020). HUBUNGAN PENGGUNAAN KONTRASEPSI HORMONAL DENGAN KEJADIAN KANKER PAYUDARA DI RSUD EMBUNG FATIMAH KOTA BATAM TAHUN 2017. Zona Kebidanan: Program Studi Kebidanan Universitas Batam, 9(2)

Notoadmodjo, 2010 . Metode Penelitian Kesehatan . Jakarta : Gramedia Manuba, 2010 . Ilmu Kebidanan . Jakarta : Pustaka Sinar Harapan

Rumengan, 2010 . Metode Penelitian dengan SPSS. Batam : UNIBA PRESS 
ZONA KEDOKTERAN - Vol. 11 No. 1 Januari 2021

Irianto,Koes , 2014 . Ilmi Kesehatan Masyarakat

. Bandung : Alfabet

Marmi, 2014 . Buku Ajar Kesehatan

Reproduksi. Yogyakarta : Pustaka

Belajar

Mulyani S.N dan Rinawati M . 2014.

Keluarga Berencana dan Alat Kontrasepsi.

Yogyakarta : Nuha Medika 